\title{
Exploring Senior High School EFL Teachers' Beliefs Regarding Learner Autonomy
}

\section{A. A. I. S. Wirapatni1 ${ }^{*}$, P. K. Nitiasih ${ }^{2}$, L. P. Artini ${ }^{3}$}

1,2,3 Ganesha University of Education, Singaraja, Bali, Indonesia

\begin{tabular}{l} 
A R T I C L E I N F 0 \\
\hline Article history: \\
Received 18 November \\
2020 \\
Received in revised \\
Form 11 January 2021 \\
Accepted 21 January 2021 \\
Available online 01 \\
February 2021 \\
\hline
\end{tabular}

Keywords:

Learner Autonomy, EFL Learning

\begin{abstract}
A B S T R A C T
Since Indonesian education paradigm shifted from teaching to learning, the development of learner autonomy is more emphasized on the learnercenteredness. Henceforth, it is important to conduct a study of teachers' beliefs regarding learner autonomy as it is widely known that teachers are recognized as an active agent to inculcate autonomy among learners. This study aims to explore EFL teachers' beliefs regarding the idea of learner autonomy and its development within senior high school settings. This study was a mixed method study that employed a questionnaire and interview as instruments to obtain the data. The participants of this study were 18 senior high school EFL teachers. The result of the study shows that teachers hold very positive beliefs toward learner autonomy. Most of the teachers believe their learners are less autonomous in learning. Learners tend to be passive and less independent of teacher. Teachers assert that they are already promoting learner autonomy within their teaching. Some efforts have been done by EFL teachers to promote autonomy among learners such as giving freedom for learners to express
\end{abstract} themselves in learning, giving learners opportunities to solve their problems as well as motivating the learners to learn English. The constraints that teachers encounter basically derived from two factors: intrinsically from the learners' low motivation to learn and extrinsically from the school facilities that are less adequate to support the development of learner autonomy.

\section{Introduction}

Learner autonomy in this twenty first century has become an attribute demanded to fulfil the needs of sustainable living. The rapid growth of current development encourages teachers to prepare better quality generation by helping learners to develop their autonomy in learning. The benefits of fostering autonomy among learners can make the learning becomes more meaningful. As the learners are given freedom in terms of deciding their own choices, they will be used to manage their learning and be more motivated to learn. Learners who have reached higher levels of autonomy capable to fulfil their learning needs and admitted as better citizens by taking control toward their own decision (Basri, 2020). Learner autonomy has been discussed in scholars over decades. It was begun with the publication of Holec's seminal report in 1981. Learner autonomy as the ability to take charge of one's own learning. Meaning that, one have to be responsible for all decisions of learning such the determining the purpose of learning, explaining the learning contents and progressions, choosing the learning technique, and reflecting their own learning (Little, 1991). He also highlighted that this ability is not inborn yet it has to be attained through natural means, one of which is formal learning. However, learner autonomy is not an easy behaviour to describe which it is complex, multidimensional and variably manifested (Benson, 2012; Najeeb, 2013).

Furthermore, since learner autonomy is seen as complex and variably manifested, there are three different perspectives to represent the idea of autonomy which consist of technical perspective, psychological perspective, and political perspective (Benson, 1997). In this case, each perspective present diverse point of views such as technical perspective emphasizes the form and situation where the learning occurs, psychological perspective emphasizes learners' mental attribute that permit autonomy, meanwhile political perspective focuses on empowering learners to control their content and processes in learning. Although Benson's versions were sufficient in to represent the concept of learner autonomy, it is still lack on the social aspects of the learning. Henceforth, Oxford elaborated the versions by adding sociocultural perspective which focuses on the social-constructivism theory where the ability can be developed through interaction and social participation (Oxford, 2003). These four perspectives may look 
divergent at a glance, but they are actually complementary in representing the idea of learner autonomy (Dang, 2012). The interest in learner autonomy has been increasing since 1980s onwards, which is denoted by the extension of its focus from adult language learning to younger learners and conventional classrooms (Benson \& Huang, 2008). The term 'learner autonomy' often misunderstood with some related concepts. To avoid some misunderstanding of this slippery term, (Benson, 2011) thus points out that learner autonomy refers to as an "attribute of learner" meanwhile the related concepts such as independent learning and self-directed learning refers to as situations or mode of learning where the learner autonomy is emphasized. However, all of these terms are basically intended to highlight the learner-centeredness in learning.

With regards to this concern, Indonesia has exerted the effort to improve the quality of its education. Indonesia has shifted its education paradigm from teaching to learning which is denoted by the implementation of 2013 curriculum. This shifting has brought number of changes in term of learning process, for instance, from traditional teacher-oriented teaching to learner-centered learning. The central control has been shifted into autonomy and trust where it is known that formerly all the controls were held by teacher but within this latest curriculum, everything has been centered on learners where they are given trust and responsibility over their learning. In a nutshell, teaching and learning nowadays is designed to help learners in learning how to learn. Despite the huge possibility that is offered by learner autonomy, its development in teaching and learning process is still lack of attention. In Indonesia, the concept of learner autonomy is reported as an almost unfamiliar concept, where it is often recognized as part of western culture which contradicts the Indonesian culture that stick firmly on the idea of eldersknow-all and teachers never be wrong (Lengkanawati, 2017). In the same vein, Cirocki, Anam, and Retnaningdyah (2019) also reported that learner autonomy in Indonesia is not well promoted. The findings of their research found many students are unfamiliar with learner autonomy which is indicated by their lack of skills as autonomous learner, their low motivation in learning, and their unpreparedness to act independently in learning. Smith, Kuchah, and Lamb (2017) pointed out that successful language learners in developing country are most likely achieved by autonomous learners who are able to confront the challenges in fulfilling their learning needs such as low availability of resources. Based on these findings, the study suggested teachers to train Indonesian students to be more involved in the learning process.

English is one of compulsory subjects that have to be acquired in Indonesia. It is in line with the consideration where English is used as the most language to connect people with different languages. Associating the desirability of learner autonomy to the importance of English in education, it was found that learner autonomy had significant positive correlation with English language proficiency and learners' learning motivation (Jianfeng, Raj, \& Ai, 2018). Cultivating English abilities through autonomous learning has been found effective to build ecological affordances for learners to utilize the existed learning resources which make the learning process more purposeful (Song, 2020). Providing learning situation where learners are given control towards their decision will improve the quality of English language teaching. Henceforth, developing autonomy among learner is crucial to increase learners' English proficiency. Benson (2011) affirmed that learner autonomy cannot be taught or learned, but it can be developed through educational activities that are used to promote learner autonomy. In this case, teacher's understanding of the concept is significant as the basis to help learners in becoming more autonomous. No matter how experienced the teachers are, it will be difficult to foster learner autonomy if teachers have lack understanding of the concept. Thus, it is seen as important to explore teacher's beliefs regarding learner autonomy to find out how actually learner autonomy means for them.

Teachers' beliefs is defined as teachers' personal constructs that include understanding, judgements and evaluation of teachers' practices (Dos Santos, 2019). One prominent research regarding teachers' beliefs of learner autonomy had been carried out by Borg and Al-Busaidi (2012) which has given important contribution to the field particularly for English Language Teaching. Their questionnaire has been used by many researchers and is recognized as grounded and robust (Lengkanawati, 2017; Melvina \& Suherdi, 2019; Wichayathian \& Reinders, 2018). Henceforth, with regards to this present study, the researcher decided to use instrument designed by Borg and Al-Busaidi (2012) to obtain the data. The intention of the study is set to explore senior high school English teachers' beliefs regarding learner autonomy in Gianyar Regency. This study is expected to give a beneficial contribution to the development of learner autonomy particularly in Indonesian settings.

\section{Methods}

This study was a mixed-method approach which employed explanatory sequential design. According to Creswell (2012), an explanatory sequential design is aimed to provide general picture of the 
research problem through two phases of data collection: quantitatively and qualitatively. The use of these two phases of data collection can refine and enrich the explanation of the analysis. The researcher decided to use simple random sampling to choose the sample of this study. In this case, the researcher chose 4 schools out of 7 schools in Gianyar Regency, Bali, Indonesia. The demographic data obtained in this study indicated that the participants were mainly male teachers. There were a higher number of experienced teachers in teaching English which was more than 10 years and they were mostly held a bachelor's degree. The objective of this study was to explored (1) senior high school EFL teachers' beliefs regarding learner autonomy, (2) the extent to which senior high school EFL teachers' perceive their learners are autonomous, (3) the extent to which senior high school EFL teachers' perceive their effort in promoting learner autonomy, and (4) the constraints that senior high school EFL teachers encounter in promoting learner autonomy.

A questionnaire designed by Borg and Al-Busaidi (2012) was adopted in this study. Borg and AlBusaidi's (2012) questionnaire is seen as a robust instrument to explore teachers' belief regarding language learner autonomy. It had been used in some previous studies (e.g Lengkanawati, 2017; Melvina \& Suherdi, 2019; Wichayathian \& Reinders, 2018). In this study, EFL teachers' beliefs were gained through a questionnaire covering four perspectives namely technical perspectives, psychological perspectives, political perspectives, and sociocultural perspectives. The researcher also employed interview guide as instrument in this study. Form of interview that was conducted is semi-structured interview. In this study, two data analysis were employed. In the quantitative data analysis, the researcher firstly collected all the teachers' questionnaire responses from google form. The data obtained then calculated by using Microsoft Office Excel to find out the descriptive statistical result as well as the percentage of each response. The questionnaire that was administered to the participants employed Likert Scale which consisted of five points. After all the results had been interpreted, the researcher continued to determine the qualification level of the belief. The researcher used the qualification level suggested by Koyan (2012, pp. 24-25). In addition, the data analysis in qualitative research was done to support the quantitative data analysis. Miles \& Huberman (1994) data analysis was used to find the qualitative data. The qualitative data analysis was used to enrich the quantitative data analysis in an explanatory sequential design.

\section{Result and Discussion}

\section{Results}

\section{Teachers' Belief of Learner Autonomy}

After all the questionnaires responses had been calculated using Microsoft Office Excel. The researcher continued to analyse the data and refined it with interview results to create a final interpretation. The result of this study found that senior high school EFL teachers in Gianyar Regency have positive beliefs regarding learner autonomy. The mean score of teachers' responses were $(\bar{X}=104.73)$ which is categorized in the interval $100.1 \leq<125.1$. As the teachers hold very positive beliefs, it can be inferred that the teachers support the idea of learner autonomy within EFL learning. The qualification level of the mean score is displayed in the Table 1.

Table 1. Qualification level of Teachers' Beliefs regarding Learner Autonomy

\begin{tabular}{ccccc}
\hline No & Criteria & Interval & Categorization & Qualification \\
\hline 1 & $\mathrm{Mi}+1.5 \mathrm{SDi} \leq \overline{\bar{X}}<\mathrm{Mi}+3.0 \mathrm{SDi}$ & $100.1 \leq \bar{X}<125.1$ & Very High & Very Positive \\
2 & $\mathrm{Mi}+0.5 \mathrm{SDi} \leq \bar{X}<\mathrm{Mi}+1.5 \mathrm{SDi}$ & $83.35 \leq \bar{X}<100.1$ & High & Positive \\
3 & $\mathrm{Mi}-0.5 \mathrm{SDi} \leq \bar{X}<\mathrm{Mi}+0.5 \mathrm{SDi}$ & $73.35 \leq \bar{X}<83.35$ & Average & Neutral \\
4 & $\mathrm{Mi}-1.5 \mathrm{SDi} \leq \bar{X}<\mathrm{Mi}-0.5 \mathrm{SDi}$ & $49.95 \leq \bar{X}<73.35$ & Low & Negative \\
5 & $\mathrm{Mi}-3.0 \mathrm{SDi} \leq \bar{X}<\mathrm{Mi}-1.5 \mathrm{SDi}$ & $24.9 \leq \bar{X}<49.95$ & Very Low & Very Negative \\
\hline
\end{tabular}

Based on the findings, teachers mostly agreed with the technical perspective. The average results showed that $72.23 \%$ teachers agreed with the statements of the technical perspective, $22.23 \%$ strongly agreed, and 5.58\% unsure with the statement. Unlike Technical Perspective, the results of teachers' response on Psychological Perspective were varied. Teachers' responses showed that $53.48 \%$ agreed, $37.04 \%$ strongly agreed, $4.94 \%$ unsure and $3.72 \%$ disagreed about the statements on the psychological perspective. On this psychological perspective, the majority of the teachers believe that learning to work alone was essential to learner autonomy. This finding also indicated that teachers have doubt to determine whether learner characteristic such as age was feasible to develop learner autonomy. The 
intrinsic factor such as motivation and confident were viewed in positive way by teachers. Teachers' responses on Political perspective showed 58.74\% agree, $26.19 \%$ strongly agree, $6.36 \%$ unsure, and $8.73 \%$ disagree. In this finding, it can be seen that teachers have positive belief about the power of choices in the learning. The finding also revealed that the role of teacher in the development of learner autonomy is demanded. Teachers' responses on the Sociocultural Perspective were all positive by which $33.34 \%$ strongly agreed and $66.66 \%$ agreed. This finding indicated that there were no disagreements showed in each item.

\section{Teachers' Views of Their Learner as Autonomous Learners}

Regarding the second research question, the researcher found that senior high school EFL teachers in Gianyar Regency mostly disagreed that their learners are autonomous. The questionnaire's responses showed that $38.9 \%$ of the teachers disagreed that their learners were autonomous, 33.33\% were unsure, and $27.8 \%$ were agreed. The researcher had provided a comment section for teachers to give more specific comments regarding their response on the questionnaire. Most of their comments indicated that the learners were not autonomous enough. The main reason that was written by teachers was their learners had low motivation to learn and they tend to be passive and dependent on teacher. Yet, there were quite few teachers who considered their learner as autonomous. In this case, teachers believed their learner as autonomous since they could use technology and seen it from their social economic background by which they lived in tourism area thus they capable to practice the language. That was one reason of why some teachers consider their learners are autonomous. The results of teachers' responses regarding the extent to which autonomous the learners are presented in the Table 2.

Table 2. The Extent to which Autonomous the Learners are according to EFL Teachers' Responses

\begin{tabular}{|c|c|c|c|c|c|c|}
\hline \multirow{2}{*}{ No } & \multirow{2}{*}{ Statement } & \multicolumn{5}{|c|}{ Teachers' Response } \\
\hline & & SA & $\mathbf{A}$ & $\mathbf{U}$ & D & SD \\
\hline 1 & $\begin{array}{l}\text { In general, the students I teach English (at } \\
\text { the current school where I work) have a } \\
\text { fair degree of learner autonomy }\end{array}$ & $0 \%$ & $27.8 \%$ & $33.33 \%$ & $38.9 \%$ & $0 \%$ \\
\hline
\end{tabular}

\section{Teachers' Effort and Constraints in Promoting Learner Autonomy}

In accordance to the realization of learner autonomy in Gianyar Regency, the researcher had asked teachers regarding their views toward their effort in promoting learner autonomy. In the openended questionnaire, the teachers were asked about their views regarding their effort in promoting learner autonomy within their teaching. Based on the teachers' questionnaire responses in the Table 3, it can be seen that teachers believed they were promoting learner autonomy within their teaching. There were no disagreements indicated by the responses. The teachers mostly agreed that they provide opportunities for learners to develop their autonomy. Based on the comments provided by teachers on the questionnaire, teachers developed learner autonomy by giving learners freedom to express themselves in the learning, motivating the learners to always be confident and giving opportunities for learners to interact directly with native speakers. They also implemented group-works which they perceived learners could take more responsibility over their learning.

Table 3. The Extent to which EFL Teacher Promote Learner Autonomy

\begin{tabular}{|c|c|c|c|c|c|c|}
\hline \multirow{2}{*}{ No } & \multirow{2}{*}{ Statement } & \multicolumn{5}{|c|}{ Teachers' Response } \\
\hline & & SA & A & $\mathbf{U}$ & D & SD \\
\hline 1 & $\begin{array}{l}\text { In general, in teaching English (at the current } \\
\text { school where I work), I give my students } \\
\text { opportunities to develop learner autonomy }\end{array}$ & $5.6 \%$ & $94.4 \%$ & $0 \%$ & $0 \%$ & $0 \%$ \\
\hline
\end{tabular}

Nevertheless, there were some constraints that confronted by teachers in promoting learner autonomy. The answers that were delivered by teachers in the interview session are in line with their responses showed in the questionnaire. The major constraint that teachers faced with regard to learner autonomy was the learners' low motivation to learn. There had been many efforts attempted by teachers to motivate the learners. Other constraint that was revealed by teachers was the school facilities which were less adequate. Additionally, the curriculum policy also perceived as one constraint that caused learners to be demotivated in learning. The teachers explained that there were too many subject matters that had to be acquired by learners. It hinders the learners' willingness to explore more on their interest, 
for instance as the learners were interested in art they cannot explore much deeper about art at school because they have to prepare themselves to acquire other subject such as science or math. That was the analogy that described by teachers to the researcher regarding the constraint that hinders learners' autonomy development in Gianyar Regency.

\section{Discussion}

Based on the findings of this study, it can be indicated that senior high school EFL teachers in Gianyar Regency held a very positive belief toward learner autonomy. On the questionnaire that were administered to teachers, all the four perspectives that representing the idea of learner autonomy had supports from teachers through their responses. The findings found in this present study echo with the study of Lengkanawati (2017), Doğan \& Hakkı (2017), Cakici (2017) and Begum (2019), indicating that teachers are desirable to inculcate learner autonomy in their teaching. In finding more information regarding what actually learner autonomy means for teachers, most of teachers stated that they considered learner autonomy as learners' initiated to learn and associated it with the learners' responsibility to find out the information with or without teachers' assistance. This result is similar as Borg \& Alshumaimeri (2017) which found most of teachers in Saudi Arabia considered learner autonomy as independence and control in completing the task individually and collaboratively. The results of this present study also indicated that most of senior high school EFL teachers in Gianyar Regency believed that learner autonomy refers to learners' independence in learning by which they were independence of teacher and they were able to search the information by themselves. Most of teachers believed that autonomous learners were those learners, who had higher sense of curiosity, having high motivation to learn, having courage to be autonomous, and also capable to socialize and share the knowledge with others. This finding is in accordance with Yasmin \& Sohail (2018), reporting that teachers' indicated autonomous learners as those who were eager to be explorer in learning and intrinsically motivated to learn more. These characteristics suit the characteristics of autonomous learners that are presented by Wenden (1998).

Most of senior high school EFL teachers in Gianyar Regency perceived their learners were less autonomous. The main reason that was written by teachers was their learners had low motivation to learn and they tend to be passive and dependent to teacher. Yet, there were quite few teachers who considered their learner as autonomous. In this case, teachers considered their learner as autonomous since they could use technology and seen it from their social economic background by which they lived in tourism area thus they capable to practice the language. Similar finding to this present study also reported in in Cirocki et al. (2019) that many Indonesian secondary school students were considered as unfamiliar with the concept of learner autonomy by which they were lack understanding of being autonomous learners. Henceforth, autonomy need to be inculcated among learners to improve the EFL learning in Indonesian context (Lengkanawati, 2017). However, there were some constraints that were encountered by teachers in promoting learner autonomy. The major constraint that was confronted by teachers was learners' lack motivation to learn. The learners' characteristics which dependent on teachers made it harder to develop learner autonomy. This constrains were also supported by the insufficient facilities that caused the leaners dependent on the teacher. Chang (2020) also revealed that there were some factors causing discrepancy between teachers' beliefs and their practices. The factors were driven from learners' passive attitudes to learn and curriculum demands. Basri (2020) pointed out some factors that need to be considered with regards to successfully promote learner autonomy such limiting power of both teacher and learner background, avoiding spoon-feeding tendencies in learning process, and matching teacher and students expectation for the learning outcomes. This present study provided general overview of senior high school EFL teachers' beliefs regarding learner autonomy in Gianyar Regency. Thus, the result of this study was expected to give positive contribution in the design of further intervention particularly in promoting learner autonomy.

\section{Conclusion}

Teachers hold very positive beliefs toward four perspectives of learner autonomy. Many of the teachers implied that they considered learner autonomy as learners' independence and learners' initiative to learn. The teachers had almost similar views about their learners with regard to learner autonomy. Most of the teachers recognized their learners as less autonomous in learning. The main reason described by teachers was because of learners' lack of motivation to learn. The majority of the teachers believed they provided opportunities for learners to develop their autonomy. They described their efforts mainly focusing on how to motivate the learners to learn such as implementing group work, giving them freedom to solve the problem, giving the learners freedom to express themselves in learning, making use of the 
internet, and adapting the learners habit to get used of being independent in learning. The teachers mentioned some factors which limited their effort in promoting learner autonomy. These factors were mainly derived from the learners and the institution. From the learners' side, the factor mostly causes by their low motivation to learn, whereas from the institution's side, the teacher admitted that school facilities were not adequate to support learner to develop their autonomy and the policy which required learners to learn so many subject matters made it less feasible to enhance learner autonomy.

\section{Acknowledgement}

The author would like to acknowledge all the EFL teachers of senior high school in Gianyar Regency who had participated and supported the present study

\section{References}

Basri, F. (2020). Factors influencing learner autonomy and autonomy support in a faculty of education. Teaching in Higher Education, 1(1), 1-16. https://doi.org/10.1080/13562517.2020.1798921.

Begum, J. (2019). Learner Autonomy in EFL/ESL Classrooms in Bangladesh: Teachers' Perceptions and Practices. International Journal of Language Education, 3(1), 12-21. https://doi.org/10.26858/ijole.v1i1.6397.

Benson, P. (2011). Teaching and Researching Autonomy. (D. R. Candlin, C. N.; Hall, Ed.) (Second Ed.). Routledge.

Benson, P. (2013). Learner autonomy. TESOL quarterly, 47(4), 839-843.. https://doi.org/10.1002/tesq.134.

Benson, P., \& Huang, J. (2008). Autonomy in the transition from foreign language learning to foreign language teaching. DELTA: Documentação de Estudos em Lingüística Teórica e Aplicada, 24(SPE), 421-439. https://doi.org/10.1590/S0102-44502008000300003.

Benson, P., \& Voller, P. (1997). Autonomy \& Independence in Language Learning. (P Benson \& P. Voller, Eds.). Addison Wesley Longman.

Borg, S., \& Al-Busaidi, S. (2012). Learner autonomy: English language teachers' beliefs and practices. ELT journal, 12(7),

$1-45$. https://www.teachingenglish.org.uk/sites/teacheng/files/b459\%20ELTRP\%20Report\%20Busai di_final.pdf.

Borg, S., \& Alshumaimeri, Y. (2019). Language learner autonomy in a tertiary context: Teachers' beliefs and practices. Language Teaching Research, 23(1), 9-38. https://doi.org/10.1177/1362168817725759.

Cakici, D. (2017). An Investigation of Learner Autonomy in Turkish EFL Context. International Journal of Higher Education, 6(2), 89-99. https://doi.org/10.5430/ijhe.v6n2p89.

Chang, L. Y. H. (2020). Taiwanese EFL language teachers' beliefs and actual practices related to learner autonomy. TESL-EJ, 23(4), 26-27. https://eric.ed.gov/?id=EJ1242713.

Cirocki, A., Anam, S., \& Retnaningdyah, P. (2019). Readiness for autonomy in English language learning: The case of indonesian high school students. Iranian Journal of Language Teaching Research, 7(2), 1-18. https://dx.doi.org/10.30466/ijltr.2019.120695.

Creswell, J. W. (2012). Educational Research: Planning, Conducting and Evaluating Quantitaive and Qualitative Research (4th Edition). Pearson.

Dang, T. T. (2012). Learner autonomy: A synthesis of theory and practice. The Internet Journal of Language Culture $\quad$ Society, 52-67. https://www.researchgate.net/profile/Tin_Dang4/publication/298092439_Learner_autonomy_A _synthesis_of_theory_and_practice/links/5fa1322d458515b7cfb5d74f/Learner-autonomy-Asynthesis-of-theory-and-practice.pdf.

Doğan, G., \& Hakkı, İ. (2017). EFL instructors' perception and practices on learner autonomy in some Turkish universities. Journal of Language and Linguistic Studies, 13(1), 166-193. https://dergipark.org.tr/en/pub/jlls/issue/36109/405456. 
Dos Santos, L. M. (2019). The relationship between teachers' beliefs, teachers' behaviors, and teachers' professional development: A literature review. International Journal of Education and Practice, 7(1), 10-18. https://doi.org/10.18488/journal.61.2019.71.10.18.

Jianfeng, C., Raj, G. S., \& Ai, J. T. T. (2018). The Correlations among Learning Motivation, Autonomy and Language Proficiency in Chinese EFL Context. LEARN Journal: Language Education and Acquisition Research Network, 11(1), 1-14. https://eric.ed.gov/?q=learning+motivation\&id=EJ1225852.

Koyan, I. W. (2012). Statistik Pendidikan Teknik Analisis Data Kualitatif. Undiksha Press.

Lengkanawati, N. S. (2017). Learner autonomy in the indonesian efl settings. Indonesian Journal of Applied Linguistics, 6(2), 222-231. https://doi.org/10.17509/ijal.v6i2.4847.

Little, D. (1991). Learner autonomy 1: Definitions, issues and problems. Authentik Language Learning Resources Ltd.

Melvina, M., \& Suherdi, D. (2019). Indonesian ELT Teachers' Beliefs toward Language Learner Autonomy. Atlantis Press, 257(Icollite 2018), 239-242. https://doi.org/10.2991/icollite-18.2019.53.

Miles, M. B., \& Huberman, A. M. (1994). Qualitative Data Analysis: An Expanded Sourcebook (2nd ed.). Sage Publications, Inc.

Najeeb, S. S. R. (2013). Learner Autonomy in Language Learning. Procedia - Social and Behavioral Sciences, 70, 1238-1242. https://doi.org/10.1016/j.sbspro.2013.01.183.

Oxford, R. L. (2003). Toward a more systematic model of L2 learner autonomy. In Learner autonomy across cultures (pp. 75-91). Palgrave Macmillan, London.

Smith, R., Kuchah, K., \& Lamb, M. (2017). Learner autonomy in developing countries. Autonomy in Language Learning and Teaching: New Research Agendas, 7-27. https://doi.org/10.1057/978-1137-52998-5_2.

Song, J. (2020). Developing English Abilities of Autonomous Learning for Undergraduates in the Environment of Ecological Affordance. English Language Teaching, 13(7), 104. https://doi.org/10.5539/elt.v13n7p104.

Wenden, A. L. (1998). Metacognitive knowledge and language learning. Applied Linguistics, 19(4), 515537. https://doi.org/10.1093/applin/19.4.515.

Wichayathian, N., \& Reinders, H. (2018). A teacher's perspective on autonomy and self-access: from theory to perception to practice. Innovation in Language Learning and Teaching, 12(2), 89-104. https://doi.org/10.1080/17501229.2015.1103245.

Yasmin, M., \& Sohail, A. (2018). A creative alliance between learner autonomy and English language learning: Pakistani university teachers' beliefs. Creativity Studies, 11(1), 1-9. https://doi.org/10.3846/23450479.2017.1406874. 